\title{
Difference of Critical Thinking Ability and Ability to Solve Mathematical Problem Students of SMP Negeri 3 Sibabangun using Metacognitive Learning Model and Inquiry
}

\author{
Amii Mardiyah Sipahutar \\ Graduation Mathematics Education Post \\ Universitas Negeri Medan \\ Medan, Indonesia \\ Amiimardiyah123@gmail.com
}

\author{
Bornok Sinaga \\ Mathematics Education \\ Universitas Negeri Medan \\ Medan, Indonesia
}

\author{
Edy Syahputra \\ Mathematics Education \\ Universitas Negeri Medan \\ Medan, Indonesia
}

\begin{abstract}
This study aims to understand: (1) Differences students' critical thinking skills at SMP N 3 Sibabangun who taught with the metacognition learning model with inquiry learning models, (2) Problems problem solving ability of students at SMP N 3 Sibabangun who are taught with metacognition learning models with students taught with inquiry learning models (3) Learning between the early mathematical abilities and learning of students' mathematical thinking abilities at SMP N 3 Sibabangun, (4) students at SMP N 3 Sibabangun. The sample of this study of class VIII-A as the experimental class I (30 students) and students of class VIII-C (30 students) as the experimental class II. The analysis used uses two-way ANAVA. The results this study indicate that: (1) There is no significant difference learning with the metacognition model and by using the inquiry model students' critical thinking skills, (2) There is no significant difference in learning with the metacognition model and with the inquiry model of the ability to solve student problems (3) There is no interaction between the learning model with the initial mathematical ability students' critical thinking skills. (4) There is no interaction between the learning model with the initial mathematical ability students' problem solving abilities.
\end{abstract}

Keywords-Critical thinking skills, problem solving skills, metacognition learning models and inquiry learning models.

\section{INTRODUCTION}

Education is an important tool in efforts to improve the quality of human resources. To get quality human resources a quality education system is also needed. In an effort to meet the demands of an education system that is capable of producing reliable human resources, the Indonesian government has made various efforts and one of them is through laws on the national education system and various other instruments that regulate the implementation of the education system. The purpose of education as formulated in Law No. 20 of 2003, Article 3, namely to develop the potential of students, to become human beings who have faith and devote to God Almighty, have noble, healthy, knowledgeable, capable, creative, independent, and become democratic and responsible citizens.

Given the important role of teachers in improving the effectiveness of the learning process, the government is working hard to improve the quality of teachers. However, this has not yet been seen as effective, because in general most of the teachers are still seen doing the conventional learning process that was usually done before. One of the weaknesses of the learning process carried out by our teachers to date is the lack of efforts to develop students' thinking abilities. Each process of learning mathematics encourages more students to master a number of subject matter. The learning is theoretical and abstract. Students' abilities are obtained through exercises, so that student behavior is built on habitual processes. This causes students not to have the opportunity to develop their thinking skills and find alternative solutions to problems, but they are very dependent on the teacher. In the end students just memorize all the concepts without understanding their meaning.

One of the high-level thinking skills of students in mathematics is the ability to think critically mathematically. The ability to think critically is a very important ability. This is as stated by Soeprapto (Liberna, 2012: 192) "The ability to think critically is an ability that is essential for life, work and functioning effectively in all other aspects of life [1]. Critical thinking has long been a staple goal in education since 1942. Research and various opinions on it, have become the topic of conversation in the last ten years ". So it can be said that critical thinking is an ability that is very important for life so that it is used as a main goal in education.

The low ability of students 'mathematical critical thinking is also obtained from the test results of a problem that measures the ability of students' mathematical critical thinking that has been given to students as follows.

Mother has several pieces of tofu, all of the same size. Each tofu has a length of $6 \mathrm{~cm}$, width $4 \mathrm{~cm}$, and height $5 \mathrm{~cm}$. I want to put that tofu into a cube shaped lunch box. What is the maximum number of tofu that can be put into the lunch box if 
the box has a surface area of $3750 \mathrm{~cm} 2$. a) What is asked and what is known from the problem ?, b) Determine the size of the volume of one tofu and the size of the side of a box, c) Determine the volume of the box, $d$ ) What is the maximum number of tofu that can be entered into the box?

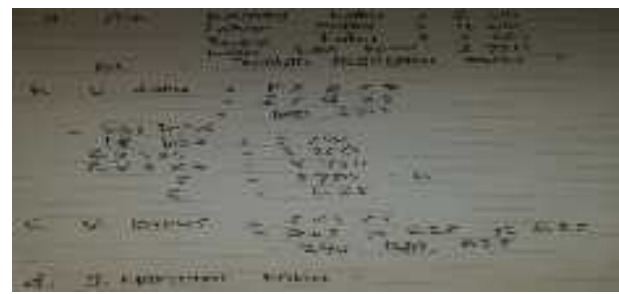

Fig. 1. Student Critical Thinking Ability Test Results

From the tests carried out obtained students who are able to answer correctly from the four indicators are at mastery level $<50 \%$ or in the low category. As for the guidelines used according to (Dikti, 2010: 8-9) categories of student mastery are as follows:

TABLE 1. CRITERIA FOR INITIAL CAPABILITIES

\begin{tabular}{|c|c|}
\hline Level of Mastery Category & Categoryi \\
\hline$\geq 70 \%$ & High \\
\hline $50 \%-70 \%$ & Medium \\
\hline$<50 \%$ & Low \\
\hline
\end{tabular}

Based on observations made it appears that students are still not able to make into mathematical models and solve critical thinking questions given to students in accordance with the steps of critical thinking skills so that it appears that students 'critical thinking abilities are still low In addition to students' critical thinking abilities, solving The problem also affects students' knowledge and understanding of mathematics

Besides the ability to think critically mathematically, a high level of ability in mathematics that still needs attention is the problem-solving ability. Problem solving is the process of applying previously acquired knowledge into new situations that are not yet known so that students are more challenged and motivated to learn them. In the learning and completion process, students are allowed to use the skills and experience they have to apply in solving non-routine problems. Thus, problem solving skills are very important to be mastered by students. Turmudi (2008: 29) explains that problem solving in learning mathematics is an inseparable part in learning mathematics [2].

According to the National Council of Teachers of Mathematics (2000: 52) revealed the goal of teaching problem solving in general is to (1) build new mathematical knowledge, (2) solve problems that arise in mathematics and in other contexts, (3) apply and adjusting various strategies suitable for solving problems and (4) monitoring and reflecting the process of solving mathematical problems [3].

The low level of problem solving ability is one of the factors that causes low student mathematics learning outcomes, because mathematics is very closely related to the level of students' mathematical problem solving abilities.
Jonassen (Purnomo, 2014: 25) emphasized that the main focus in learning should be to learn to solve problems [4]. This is also explained by Branca that the ability to solve problems is the main goal in learning mathematics, therefore the ability to solve problems should be given, trained, and accustomed to students. Then Loretta Ohnemus Omaha, Nebraska (2010: 5) asserted "Problem solving is an essential part of mathematics, yet many students spend much of their mathematics career copying and reproducing algorithms". Which means that problem solving is the most important part in Mathematics, but there are still many students who cheat and produce algorithms in their mathematics lessons [5].

But the fact is the ability of students in problem solving is still relatively low, this can be seen after being tested on students in one of the schools, showing that the ability of students in problem solving is still relatively low, following is one example of the problem given to students who measure their ability to solve student mathematical problems.

Mr. Budi has a cube shaped bathtub with $60 \mathrm{~cm}$ long ribs. however, Mr. Budi wants to make / rebuild a bathtub with the same shape with a volume of 512 liters larger than Mr. Budi's previous tub. a) From the story above, what information can you gather. b) From the information you have collected, can you calculate the length of Mr. Budi's new bathtub? If yes, write down your idea. c) What is the length of Mr. Budi's new bathtub?

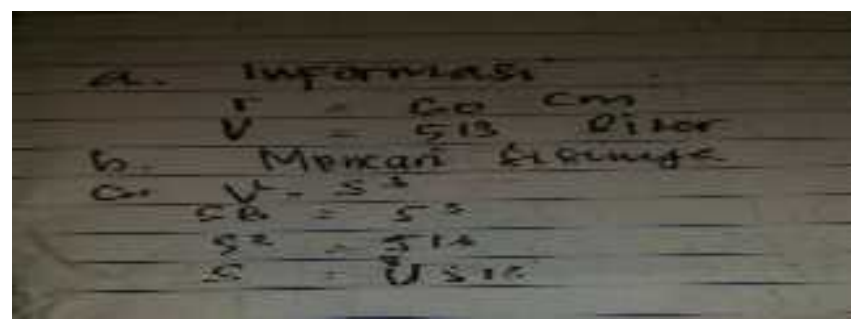

Fig. 2. Student Answers in Resolving Problems I

From the tests carried out obtained students who are able to answer correctly from the three indicators are at mastery level $<50 \%$ or in the low category. The guidelines used according to (Higher Education, 2010: 8-9) categories of student mastery in Table 1 .

Based on the explanation above it appears that the ability to think critically and problem solving is a very important ability that must be developed. However, this is still contrary to the results obtained from the learning process that has taken place. Where the ability to think critically and students' mathematical problem solving is still relatively low. Therefore the teacher should emphasize the active role of students in the learning process, providing space for students to build their knowledge by facilitating students learning resources that are in accordance with the characteristics of students as well as the characteristics of critical thinking skills and problem solving.

Susanto (Karim and Normaya, 2015: 92) states that the effort to form an optimal critical thinking ability of students requires interactive classes, students are seen as thinkers not 
being taught, and teachers act as mediators, facilitators, and motivators who help students in learning not teaching [6]. The same thing was also conveyed by Marsigit (2011: 9) stating that in order to learn mathematics optimally the teacher's function as a good facilitator is needed. Referring to this opinion, it can be concluded that the teacher as a facilitator needs to develop learning tools with appropriate learning on comparative material to meet student needs [7].

In the learning process, strategies in teaching and learning are very important to support the achievement of the expected goals. By choosing a good teaching and learning strategy will also be able to attract the active role of students in the learning process that is tailored to the model used. Piaget (Adibah, 2013: 2) views learning based on three assumptions, namely: 1) Focusing on the child's thought process, not just the results; 2) Emphasizing the important role of students in their own initiative and active involvement in learning. In classroom learning, knowledge is given without pressure, but children are encouraged to find themselves through the process of interaction with their environment; 3) Understanding the existence of individual differences in the progress of development so that the teacher must make special efforts to arrange class activities in the form of individuals or groups [8].

Metacognitive knowledge refers to the acquisition of knowledge about cognitive processes, knowledge that can be used to control cognitive processes. Whereas metacognitive experiences are processes that can be applied to control cognitive activities and achieve cognitive goals. This ability is carried out through actions among four classes of phenomena, including metacognition knowledge, metacognitive experiences, goals or tasks, and actions or strategies (Kuntjojo, 2009: 1) [9].

In conjunction with learning mathematics metacognition can play a role in helping students solve the problems at hand. According to Schoenfeld (1992) there are 3 different aspects of metacognition that are relevant to mathematics learning, namely: (1) Beliefs and Intuitions. Having ideas about mathematics that are prepared to solve mathematics and how these ideas form a way to solve problems, (2) Knowledge of someone about the process of thinking, in this case how someone describes their thinking precisely. Here we need an understanding of what he knows, and how to complete the tasks made, and (3) self-awareness or self-regulation. How does one control what he has done, the problem that has been solved and how well he uses observations to solve the problem [10].

While inquiry learning is a learning activity that maximally involves all students' abilities to search for and investigate something (objects, people or events) systematically, critically, logically analytically so that they can find their findings with confidence. Gulo (Trianto, 2011: 166) states that the inquiry learning model is a series of learning activities that maximally involve all students' abilities to search and investigate systematically, critically, logically, analytically, so that they can formulate their findings with confidence [11]. According to Hamruni (2012: 100) the advantages of inquiry learning models are (1) emphasizing the development of cognitive, affective, and psychomotor aspects in a balanced manner, so that learning through this strategy is considered more meaningful, (2) providing opportunities for students to learn according to their learning styles , (3) according to the development of learning psychology is a process of behavior change through experience, (4) able to serve the needs of students who have abilities above average, so students who have good learning abilities will not be hampered by students who are weak in learning [12].

Based on these explanations it is suspected that the metacognition learning approach and inquiry learning have similar characteristics with critical thinking skills and problem solving, so it is expected that the application of the metacognition learning approach and inquiry learning can improve both abilities. This is also evident from the results of previous research conducted by Maulana (2008) that the critical thinking skills of students who take mathematics learning using metacognitive are significantly better than students who study conventionally. Critical thinking skills of students who learn with metacognitive are in the good category, while students who study conventionally have critical thinking skills that are classified as moderate. Students in the experimental group who had the final ability to think critically mathematically in the sufficient category were $49 \%$, $47 \%$ good category, and $4 \%$ with a very good category [13]. Telaumbanua, Sinaga and Surya's (2017: 78) research results also show that students 'problem solving abilities are increased by using mathematics modules based on metacognitive strategies, in other words that students' mathematical problem solving abilities increase by using metacognition strategybased models. Then based on the background description of the problem above, the researcher will conduct research under the title "Differences in Critical Thinking Ability and Mathematical Problem Solving of Sibabangun Middle School 3 Students in Metacognition Learning and Inquiry Learning" [14].

\section{RESEARCH METHOD}

This study uses an experimental method in the form of a quasi-experimental design, a research instrument in the form of a critical thinking ability test consisting of 3 questions and a problem solving ability test consisting of 3 questions. After the test, then the data analysis is carried out in the form of homogeneity test, using the $\mathrm{F}$ test, normality test, using Kolmogorov-smirnov and hypothesis testing using two-way anova with interaction. Calculation of research results using Excel 2010 and SPSS 22.

\section{RESULT AND DISCUSSION}

The research discussion that will be presented by the researcher is to describe and discuss the results of the research. Guided by relevant theories and research will then be linked to the research findings of researchers while in the field. As for the description of several factors related in this study are as follows: 


\section{Students' Critical Thinking Ability}

From the calculation results, it was found that there are differences in learning with the metacognition model and with the inquiry model of students' critical thinking skills. In other words there are differences in learning with the metacognition model and inquiry model on the students' mathematical critical thinking skills significantly. Students who follow learning by learning metacognition models and inquiry have different phases but both models have accustomed students actively in solving problems of thinking individually to get concepts. Because the learning process is not just transferring knowledge from the teacher to students, but a process that is conditioned or sought by the teacher, so students are active in various ways to build their own knowledge.

According to Ennis (1985), then according to Simbolon, Manullang, Surya, and Syahputra, (2017: 82-90) argues "critical thinking is to think reasonably and effectively with an emphasis on making decisions about what to believe or do" meaningful thinking Critical is thinking naturally and effectively with an emphasis on making decisions about what to do [15].

During the concept construction process, students are required to have good critical thinking skills so that students can understand the concepts being studied. Someone with critical thinking skills will be aware of using cognitive skills or strategies to improve the desired results (Magno, 2010) [16]. Increasing student awareness in the learning process is very important, while skills that can facilitate students to be aware and monitor the learning process themselves are not always possessed by students. Therefore, training is needed to train students' critical thinking skills (Lalang, C.A., Ibnu, S and Strisno, 2017) [17].

In the research of Simbolon, Mulyono, Surya, and Syahputra, (2017: 725-731) states "The ability to think critically low due to the learning of mathematics has only described the steps to simply calculate without helping the student to put the ideas / ideas in oral and written form. In resolving the problems seen students are given less enthusiastic to solve the appropriate capabilities [18]. Then, the students don't feel compelled to reason and think further how to solve the given problem ". Recognizing the importance of critical thinking skills students need to seek learning to encourage students to practice those skills. Therefore the change in view learning from teachers teaching to student learning has to be the primary focus in every math learning activities ", which means the ability to think critically is low because mathematics learning only describes steps to only count without helping students to put ideas in oral and written form. students who look less eager to complete appropriate abilities. Then, students do not feel compelled to reason and think further how to solve the given problem ". Recognizing the importance of critical thinking skills students need to find learning to encourage students to practice the skills. Therefore, changes in the view of learning from teacher teaching to student learning must be the main focus in every mathematics learning activity.

\section{Interaction between Learning Model and KAM on Critical Thinking Ability}

From the results of the analysis of the calculation of research conducted on metacognition learning models and inquiry learning models with initial mathematical abilities (low, medium, high) on students' critical thinking abilities indicate that there is no interaction. That is, the average difference in tests of mathematical critical thinking skills among students of the low, medium and high categories learned through the metacognition learning model with students who are taught with inquiry learning models are not significantly different. This shows that there is no joint effect contributed by the metacognition learning model and inquiry model with students 'initial mathematical ability (low, medium, high) on students' mathematical critical thinking abilities.

There are several things in the research that indicate the possibility that there is no interaction between the learning model and the initial ability of mathematics to the ability to think critically mathematically including the following: , (2) the form of initial mathematics ability tests in the form of multiple choices, allows students to answer questions by guessing the answers of the options provided, and (3) related to the grouping of initial mathematical abilities, this is due to the grouping of initial mathematical abilities student researchers are guided by the acquisition of student scores on the initial math ability test taken from UN questions that do not reflect the students' expected mathematical critical thinking skills, so that students who have high, medium, and low mathematical initial abilities do not represent development skills. the actual beginning ability of mathematics.

Besides the initial mathematical ability factor, there are other possible factors that cause no interaction, namely the learning differences that are used. This study uses a metacognition learning model and inquiry learning model. Theoretically, in learning with the metacognition model and inquiry there is a stage where students in groups discuss learning, demand work and present work that allows interaction between groups and the teacher has a role in conditioning. However, based on observations during conducting research most students are still not active in groups even just silence without communicating with their group friends. Some students only bother their friends, while their group friends prefer to answer the LAS questions themselves. So the expected learning is less than optimal. Thus the learning model is thought to be the reason for the absence of interaction between the learning model with the initial ability of mathematics to the mathematical critical thinking ability of students.

In addition, by knowing students' initial abilities that vary teachers can choose learning models that are suitable for use in class so that learning that takes place in class can be effective. Based on research conducted by Jumaisyaroh, Napitupulu, and Hasratuddin stated that students' initial mathematical abilities need to be considered by teachers 
before conducting learning due to a hierarchy in learning mathematics, meaning that understanding new material requires mastery of previous material and in this study it is suspected that there will be interaction between initial mathematical abilities and learning towards increasing students' mathematical critical thinking abilities and learning independence.

\section{Students' Problem Solving Abilities}

From the calculation results, it was found that there are differences in learning with the metacognition model and with the inquiry model of students' problem solving abilities. In other words there are differences in learning with the metacognition model and inquiry model on the students' mathematical problem solving abilities significantly. Students who follow learning by learning metacognition models and inquiry have different phases but both models have accustomed students actively in solving problems of thinking individually to get concepts. Because the learning process is not just transferring knowledge from the teacher to students, but a process that is conditioned or sought by the teacher, so students are active in various ways to build their own knowledge. In line with Piaget which emphasizes the importance of student motivation and facilitation by the teacher. So that children's intellectual development can take place optimally, they need to be motivated and facilitated to build theories that explain the world around them.

From Lubis, Siagian, and Syahputra's research, "Mathematical problem solving as the process of interpreting a mathematical situation, which usually involves several iterative cycles of expressing, testing, and revising mathematical interpretation and sorting out, integrating, modifying, revising or refining clusters of mathematical concepts that have meaning Mathematical problem solving as a process of interpreting mathematical situations, which usually involves several repetitive cycles to express, test, and revise mathematical interpretations and sort, integrate, modify, revise or revise Mathematical concept groups of various topics inside and outside mathematics.

Mathematical problem solving by paying attention to the process of finding answers based on problem solving steps (understanding problems; planning problem solving; solving problems; and checking again) presented by Polya, in line with the opinions of Marbun, Siagian, and Masyur, "Problem solving is seen as a process to determine the combination of a number of rules that can be applied in an effort to overcome a new situation. Problem solving skills are very important for students and their future meaningful. Problem solving is seen as the process of determining a combination of a number of rules that can be applied in an effort to overcome a new situation. Problem solving skills are very important for students and their future.

According to Ritonga, Syahputra, and Surya, "Problem solving is an important component of mathematics education because it is easy to use individually or in groups. solving the problem is the process of applying the knowledge that has been acquired previously to new situations and differen "where problem solving is an important component of mathematics education because it is easy to use individually or in groups. problem solving is the process of applying previously acquired knowledge to new and different situations.

\section{Interaction between Learning Model and KAM on Students' Problem Solving Ability}

From the results of the analysis of the calculation of research conducted on metacognition learning models and inquiry learning models with initial mathematical abilities (low, medium, high) on students' problem solving abilities indicate that there is no interaction. That is, the difference between the average tests of mathematical problem-solving ability between students in the low, medium and high categories learned through the metacognition learning model with students who were taught with the inquiry learning model did not differ significantly. This shows that there is no joint effect contributed by the metacognition learning model and inquiry model with students 'initial mathematical ability (low, medium, high) on students' mathematical critical thinking abilities.

In addition to the initial mathematical ability factor, there are other possible factors that cause no interaction, namely the situation in the school environment both in terms of student interest in learning that still needs to be improved, the state of school facilities that are still lacking, and the economic aspects of parents of students and others should. This makes it so that research is solely influenced by the learning model applied.

In line with that in mathematics learning it is necessary to pay attention to students' initial mathematical abilities (Arend, 2008). In improving problem solving abilities, mathematical initial ability (KAM) also plays a very important role. According to Ali Shodikin (2015) In the learning process, this KAM will assist students in developing ideas that emerge gradually so as to build a comprehensive mathematical concept from the information obtained. The KAM students in this study were categorized into three categories namely top, middle and bottom. This grouping is used to see in more detail the effects of learning in each KAM category. In addition, it is also used to see whether there is a shared influence (interaction) between learning undertaken with KAM on improving problem solving abilities

\section{CONCLUSION}

Based on the results of research and discussion, obtained the following conclusions:

1. There are significant differences in learning with the metacognition model and by using inquiry models for students' mathematical critical thinking skills,

2. There are significant differences in learning with the metacognition model and with the inquiry model of the problem solving abilities of students.

3. There is no interaction between the learning model with the initial mathematical ability of students' mathematical critical thinking abilities. 
4. There is no interaction between the learning model with the initial mathematical ability of students' problem solving abilities.

\section{REFERENCES}

[1] Liberna, H. 2012. Peningkatan Kemampuan Berpikir Kritis Matematis Siswa Melalui Penggunaan Metode Improve pada Materi Sistem Persamaan Linear Dua Variabel. Jurnal Formatif. Vol. 2.No. 3.

[2] Turmudi. 2008. Landasan Filsafat dan Teori Pembelajaran Matematika (Berparadigma Eksploratif dan Investigatif). Jakarta: Leuser Cipta Pustaka.

[3] NCTM. 2000. Principles and Standarts for mathematics, Reaston, VA: NTCM.

[4] Purnomo. E. A. \& Mawarsari. V. D. 2014. Peningkatan Kemampuan Pemecahan Masalah Melalui Model Pembelajaran Ideal Problem Solving Berbasis Project Based Learning. Jurnal JKPM. Vol: 1. No: 1.

[5] Nebraska \& Omaha. L.O.2010.Journal writing to Learn problem solving. Lincoln: Department of Mathematics University of Nebraska.

[6] Karim\&Normaya. 2015. Kemampuan Berpikir Kritis Siswa dalam Pembelajaran Matematika dengan Menggunakan Model Jucama di Sekolah Menengah Pertama. EDU-MAT Jurnal Pendidikan Matematika. Vol, 3.No, 1.

[7] Marsigit. 2011. Pengembangan Nilai-nilai Matematika dan Pendidikan Matematika sebagai Pilar Pembangunan Karakter Bangsa. Dipresentasikan pada: Seminar Nasional Pengembangan Nilai-nilai dan Aplikasi dalam Dunia Matematika Sebagai Pilar Pembangunan Karakter Bangsa. Sabtu, 8 Oktober 2011 Di Universitas Negeri Semarang.

[8] Adibah, F. 2013. Pengembangan Perangkat Pembelajaran Matematika dengan Pendekatan Inkuiri di Kelas VIII MTs Negeri 2 Surabaya. Jurnal Widyaloka Ikip Widyadarma Surabaya.Vol, 1.No, 1.

[9] Kuntjojo. 2009. Metakognisi dan Keberhasilan Belajar Peserta Didik. http://ebekunt.wordpress.com/2009/04/12/metakognisi-dan keberhasilan-belajar-peserta-didik/. Diakses pada 14 Agustus 2009
[10] Schoenfeld, A.1992. Hand Book of Researh on Mathematics Teaching and Learning, McMillanCo.New York.

[11] Trianto. 2011. Mendesain Model Pembelajaran Inovatif Progresif. Jakarta: Kencana Prenada Media Group.

[12] Hamruni. 2012. Strategi Pembelajaran. Yogyakarta: Insan Madani.

[13] Maulana. 2008. Pendekatan Metakognitif Sebagai Alternatif Pembelajaran Matematika untuk Meningkatkan Kemampuan Berpikir Kritis Mahasiswa PGSD. Jurnal Pendidikan Dasar. Nomor. 10.

[14] Telaumbanua, Y. N., Sinaga, B,.Mukhtar\& Surya, E. 2017.Development of Mathematics Module Based on Metacognitive Strategy in Improving Students' Mathematical Problem Solving Ability at High School.Journal of Education and Practice.8(19).73-80.

[15] Simbolon, M., Manullang, M,. Surya, E., Syahputra, E. 2017. The Efforts to Improving the Critical Thinking Student's Ability Through Problem Solving Learning Strategy by Using Macromedia Flash at SMP Negeri 5 Padang Bolak. ISSN 2394-9686International Journal of Novel Research in Education and Learning Vol. 4, Issue 1, pp: (82-90), Month: January -February 2017, Available at: www.noveltyjournals. Com

[16] Magno, C. 2010. The Role of Metacognitive Skills in Developing Critical Thinking.Springer Science Business Media, LLC (Limited Liability Company), 5:137-156.https://doi.org/10.1007/s11409-0109054-4

[17] Lalang C.A., Ibnu, S. danSutrisno. 2017. KemampuanBerpikirKritis Dan Pemahaman Konseptual Siswa Dengan Inkuiri Terbimbing Dipadu Pelatihan Metakognisi Pada Materi Kelarutan dan Ksp. Jurnal Pendidikan: Teori, Penelitian, dan Pengembangan Volume: 2 Nomor: 1 Bulan Januari Tahun 2017 Halaman: 12-21. EISSN: 2502-471X

[18] Simbolon, M., Mulyono, Surya, E., Syahputra, E. 2017. The Efforts to Improving the Mathematical Critical Thinking Student's Ability through Problem Solving Learning Strategy by Using Macromedia Flash.American Journal of Educational Research, 2017, Vol. 5, No. 7 725-731 Available online at http://pubs.sciepub.com/education/5/ 